\title{
Imposition, adoption, and resistance in Lynne Kutsukake's The Translation of Love: A postcolonial approach
}

\author{
'Bhakti Satrio Nugroho*, 1Muhammad Arif Rokhman \\ American Studies Master's Program, Universitas Gadjah Mada, Yogyakarta, Indonesia
}

*Corresponding Author

Email: bhakti.landt@gmail.com

\begin{abstract}
This paper, which is under Transnational American Studies and Postcolonial Studies, aims to analyze a process of creating a colonial culture which involves cultural imposition, adoption, and resistance in Lynne Kutsukake's The Translation of Love. This novel depicts postwar Japanese society that lives under American power after the end of World War II while undergo kyodatsu (the period of an economic, social and moral crisis caused by the war). This paper is a qualitative research that utilizes three theories, including cultural imposition, mimicry and symbolic resistance. The finding, shows the devaluation of Japanese cultural identity which used to oppose the claim of "otherness" by the West. In cultural imposition, the United States manages to impose American ideology, language, lifestyle, customs and fashion through various ways such as media, social interaction, social obligation and school curriculum. Meanwhile, in cultural adoption, postwar Japanese adopt American cultures in which it asserts that there is a shift of postwar Japanese cultural orientation that tends to celebrate American culture as a "sign of liberation". Then, in symbolic resistance, postwar Japanese resistance toward the United States as the occupying power is only manifested in subversive everyday gestures which include covert and overt form. In short, this analysis shows that, during U.S. occupation, postwar Japan only becomes "a pawn" in the United States' postwar plan for global dominance by rebuilding a new Japanese society under American influence.
\end{abstract}

Keywords: postwar Japan; postcolonial; the United States; transnational; World War II

$\begin{array}{llll}\text { Received: } & \text { Revised: } & \text { Accepted: } & \text { Published: } \\ \text { 2 June 2020 } & \text { 16 August 2020 } & \text { 25 August 2020 } & \text { 31 August 2020 }\end{array}$

\section{INTRODUCTION}

World War II marked the Japanese effort to counter and challenge the West, especially European domination of the globe by establishing a new Europeanstyle empire on the edge of Asia (Watson, 2007). However, after its surrender in August 1945, Empire of Japan was forced to accept U.S Initial PostSurrender Policy for Japan, which initiated U.S. occupation of Japan (Borton, 
Nugroho, B.S., \& Rokhman, M.A. (2020). Imposition, adoption, and resistance in Lynne Kutsukake's The Translation of Love: A postcolonial approach. EduLite: Journal of English Education, Literature, and Culture, 5 (2), 345-358. DOI: http://dx.doi.org/10.30659/e.5.2.345-358

1948). This military occupation had two main objectives. First, this occupation was made to eliminate Japan's war potential in the future by punishing "those who have deceived and misled the Japanese during the war". Second, this occupation intended to turn postwar Japan from totalitarian, ultranationalist and fascist government into a democratic-style nation by establishing American concepts of the nation such as freedom of speech, of religion, and of thought, as well as respect for the fundamental human rights (Kumano, 2007). Therefore, postwar Japan was set to be exclusively supervised under foreign military control, Supreme Commander for the Allied Powers (SCAP), led by the United States.

Due to its influential aspect, U.S. occupation of Japan becomes a literary theme for Lynne Kutsukake's debut novel, The Translation of Love (2016) which was intentionally written to tell her family story of being JapaneseCanadian during that certain period. The Translation of Love itself tells a complex story of Fumi Tanaka who is in a quest to find her sister, Sumiko Tanaka who works as a bar girl to accompany GIs (U.S. soldiers), with the help of her new friend, Aya Shimamura during the occupation. As a debut novel, this novel has received many praises from New York Times and The Globe and Mail journalists for offering rich insights into an underreported period of Japan's, the United States' and Canada's history (Trilby, 2016).

Thus, due to its significance of Lynne Kutsukake's The Translation of Love as a historical-themed novel, this research aims to elaborate and analyze the process of creating colonial culture, which includes imposition, adoption and resistance during U.S. occupation of Japan in this novel by using postcolonial perspective, under Transnational American Studies. The imposition, adoption and resistance are important to discuss because they are a vital core in the process of creating a colonial culture in the colonized country. In conducting an in-depth analysis, this research utilizes three main theories: cultural imposition, mimicry and symbolic resistance to answer research questions of the cultural imposition of American culture, the postwar Japanese adoption toward American culture that is imposed, and the postwar Japanese resistance as the occupied power in this novel.

Transnational American Studies is a paradigm within American Studies to critically explore American culture and to discuss "the role of the United States in changing the world order" (Fluck et al, 2007, p. 1). As Rowe asserts: “'Transnationalism' also refers to American Studies done by international scholars outside the U.S. especially scholarship that emphasizes the influence of the U.S. abroad" (2014, p. 1). It explains how the United States becomes a central dominant country to dominate and imperialize other countries through its political and economic power.

Meanwhile, in definition, postcolonial studies or postcolonialism is an intellectual approach, which focuses on "the contestation of colonial domination and the legacies of colonialism" (Loomba, 2005, p. 16). This dialectical concept does not only discuss the broad historical facts of decolonization and the determined achievement of sovereignty but it also discusses the realities of nations and peoples emerging into a new imperialistic context of economic and political domination (Young, 2016). It concerns on 
both negative and positive effects of the mixing of peoples and cultures (Young, 2016). It is critically used to analyze socio-humanities aspects that are circled around colonization and its chained legacies, which mostly the power and colonial relation.

In this context, Transnational American Studies is able to work alongside postcolonial studies as a fundamental paradigm. The combination of both creates a larger scope in translating a topic of discussion since it provides two important contexts in one discussion: transnationality and postcoloniality. It means that it is able to discuss the American influence and domination abroad and the imbalance power relations within its domination. In American Studies research, the discourse of Western colonialism and imperialism is often placed within Transnational American Studies, which is intended to discuss the domination of the United States over the less powerful nations (Third World). Therefore, as a research paradigm, Transnational American Studies and postcolonial studies work as a strong tool to examine American domination and influence toward other countries. Thus, under these paradigms, this research utilizes three main theories: cultural imposition, mimicry and symbolic resistance, which aim to analyze a process of creating a colonial culture in the novel.

\section{Cultural Imposition}

In the cultural perspective, colonization is defined as a cultural imposition, in which the colonizer tries to impose its culture to the colonized,

The colonialists [colonizers] see their culture as a superior culture usually tied to either Cultural Evolutionary or Social Darwinist theories. In an attempt to control reap economic dismantle the native cultures by imposing their own [cultures]. There is destruction of the cultural values and ways of life. (Kortright, 2003, p. 6)

In this view, based on their cultural superiority, the colonizers impose their own culture to the colonized by demeaning the colonized's culture. They further modify and even replace the colonized's cultural value with their own due to the sense of superiority as a race, culture and civilization. Language and dress, for instance, were defined and constructed through the ideology and values of the colonizer. Moreover, it causes an erosion of native cultures which "devalue and define the identity of the native problem" (Kortright, 2003). As a result, the natives began to identify their own culture as something shameful, outdated, and not good. Thus, there is degradation and devaluation of cultural purity due to the advent of colonizer's culture.

\section{Mimicry}

Mimicry is widely known in postcolonial studies to determine the colonized's respond toward the colonizer. In definition, Bhabha defines:

...colonial mimicry is the desire for a reformed, recognizable Other, as a subject of a difference that is almost the same, but not quite. Which is to say, that the discourse of mimicry is constructed around an ambivalence; in order to be 
Nugroho, B.S., \& Rokhman, M.A. (2020). Imposition, adoption, and resistance in Lynne Kutsukake's The Translation of Love: A postcolonial approach. EduLite: Journal of English Education, Literature, and Culture, 5 (2), 345-358. DOI: http://dx.doi.org/10.30659/e.5.2.345-358

effective, mimicry must continually produce its slippage, its excess, its difference. (Bhabha, 2004, p. 122)

The disparity between the colonizer and the colonized result in the reformation of the colonized as "recognizable Other" by mimicking and adopting behaviors, attitudes, language and culture of the colonizers. The process of mimicking the Self by the Other, creates hybridity and ambivalence. Hybridity emerges as a negotiation between the Self and the Other involves the process of amalgamation, which results in "the loss of purity" within indigenous culture. Meanwhile, in definition, ambivalence is defined as "a continual fluctuation between wanting one thing and wanting its opposite" (Young in Ashcroft et al, 2007 , p. 10). Theoretically, it is also defined as a person who experiences opposing emotions and attitude regarding the colonial changes brought by the colonizer during the colonization. Thus, both hybridity and ambivalence cannot be entirely separated from mimicry due to their strong correlation in a postcolonial discourse.

\section{Symbolic Resistance}

James Connolly describes symbolic resistance as, “... a variety of acts attesting to the patriotism of the occupés [the colonized]" (2018, p. 223). Therefore, it consists of moral opposition or patriotism that demonstrates the loyalty to its own nation and its refusal to be subdued by the colonizer. As a basic foundation of Connolly's symbolic resistance, everyday forms of resistance is defined as activities that are considered political because they constitute a form of collective action in ignoring the most vital means by which lower classes manifest their political interests (Scott, 1989, p. 33). Therefore, the colonized's patriotism and self-determination as a sovereign nation can contribute as a driving factor of symbolic everyday resistance to oppose the foreign occupying power.

\section{METHOD}

This research is a qualitative which is defined as "a means for exploring and understanding the meaning individuals or groups ascribe to a social or human problem" (Creswell, 2009, p. 3). This method is regarded as the most effective way in conducting this research due to its emphasis on the researcher's interpretation toward the data. In conducting a qualitative research, it relies on qualitative data, which mean material things which are used by the researcher to investigate (Leedy, 2009, p. 86). Moreover, technique data analysis is needed to classify and to arrange the data based on the research purposes and objectives (Mahsun, 2005, p. 253), which include (1) data selection, (2) data interpretation, and (3) data conclusion.

\section{FINDINGS AND DISCUSSION}

\section{American cultural imposition in Lynne Kutsukake's The Translation of Love}

The Translation of Love illustrates the superiority of American power over the defeated Japan and kyodatsu (the period of an economic, social and moral crisis caused by the war) in which the United States, as the occupying power 
began to impose some policies and cultural values that postwar Japanese are not strongly able to resist. This imposition later plays an important role in politically and culturally "democratizing" the occupied Japan. In this research, the finding of this part shows that American cultural imposition is divided into five forms of imposition: American Ideology, language, custom, Western dating, and fashion.

The first imposition is American ideology. The novel shows the imposition of American democracy and individualism can be seen through school curriculum and social interaction. In school curriculum, for instance, under U.S. occupation authority, Minami Nishiki Middle School where the main characters, Fumi and Aya study, implements new curriculum based on American democracy and individualism (Kutsukake, 2016, p. 21). In this case, Democracy is an essential aspect of American culture, which emphasizes freedom of speech as a part of individual rights, which then manifested in American society as a democratic culture (Balkin, 2016, p. 1054). Meanwhile, individualism emphasizes the individual's moral worth (Tocqueville, 1990, p. 293). It becomes a core and characteristic of American culture, which then builds national consciousness (Arieli, 1964, p. 32). Therefore, the imposition of individualism challenges the collectivism within Japanese culture, which was already embedded in their social environment as part of their cultural value (Markus \& Kitayama, 1991). Japanese collectivism results in "the culture of shyness" in which Japanese people hesitate to express their own opinion in public (Aizawa \& Whatley, 2006). The implementation of American individualism in postwar Japanese society contradicts the core of Japanese culture which strongly consists of collectivism. It can be seen in the novel when some of Japanese characters began to openly speak about what they want, but, at the same time, also experience a hesitation in doing so.

Thus, under U.S. occupation authority, postwar Japanese undergo a construction of new ideologies, democracy and individualism, which may oppose traditional Japanese moral stance, in this case, collectivism. Geertz argues that the construction of a new ideology is a response to stress in a culture caused by the failure of its traditional ideologies (1973). It means that, by imposing American ideologies, there is a devaluation of Japanese cultural values under U.S. occupation. Moreover, as the colonized that do not have enough power to resist, postwar Japanese is spooned and culturally bombarded with American ideologies to provide an easy way to further social and cultural exploitation.

The second imposition is language. In the story, similar to American ideology, the imposition of English can be seen through school curriculum, media and social interaction since both subjects are subsequently implemented. In this case, due to U.S. occupation authority's superiority, Japanese schools should implement curriculum changes coined by Americanled government to promote and propagate American democracy. For instance, at Minami Nishiki Middle School, English now becomes the primary goal of education in postwar Japan education. In fact, the arrival of a JapaneseCanadian repatriated student, Aya Shimamura is welcomed by Kondo Sensei and School principal because she is expected to boost English teaching (Kutsukake, 2016). However, as a Japanese-Canadian who was born in 
Nugroho, B.S., \& Rokhman, M.A. (2020). Imposition, adoption, and resistance in Lynne Kutsukake's The Translation of Love: A postcolonial approach. EduLite: Journal of English Education, Literature, and Culture, 5 (2), 345-358. DOI: http://dx.doi.org/10.30659/e.5.2.345-358

Canada, she does not fluently speak both Japanese and English. In fact, she seems to experience a cultural shock which is a result of diasporic experience (Makodamayanti \& Wulandari, 2019). It is manifested in her confusion and stress in the beginning of the story and it does not actually help the improvement of English teaching in her new school.

In a broader perspective, English imposition at Minami Nishiki Middle School new curriculum contradicts the concept of Japanese national purity (kokusui-shugi) and the distinctive characteristics of Japanese people (kokutai) which abolished English teaching in pre-occupation Japanese schools (Fujimoto-Adamson 2006). Therefore, there is a devaluation of Japanese pride toward their native language which now begins to prioritize English as the language of the occupying power. It can be seen later in the emergence colloquial languages, like "panlish", as a result of Japanese comfort women's effort to engage with U.S. soldiers (Sakamoto, 2010).

The third imposition is "free relations between men and women" (jiyu $u^{-}$a danjo ko-sai) in the form of Western dating (abekku). It is a new lifestyle for postwar Japanese society which can be seen through social interaction and media. For instance, during their visit at the Great Buddha statue, Sumiko's friend, Yoko and a U.S. soldier, Sergeant Jake Pickersgill, show their Westernstyle dating by intimately holding hands and other physical contacts between a couple (Kutsukake, 2016). This public intimacy historically does not represent Japanese culture prior to the occupation. In Japanese cultural value, physical intimacy including holding hand and kissing was considered as an offence against public decency (McLelland, 2010). In fact, in Japanese culture, there is no concept of dating in Western definition. Japanese women should walk a few steps behind their husband or men. It refers to a saying onna was sanppo sagatte which means, "woman should follow three steps behind" (Roibu \& Roibu, 2017). Thus, it shows that there is a shifting of cultural value dealing with romantic and intimate relation between men and women.

The fourth imposition is American custom that did not particularly exist before the occupation. In this novel, the social interaction between U.S. soldiers and postwar Japanese affects Japanese nativeness. American custom mostly influences postwar Japanese society consists of two forms: chewing gum and Western eating custom. For instance, at Minami Nishiki Middle School, as depicted by U.S. soldiers, chewing gum becomes an exciting aspect to study by these young Japanese students since gum is typically new for postwar Japanese (Kutsukake, 2016, p. 45). In this case, chewing is an iconic manner, which represents "America" during the war (Redclift, 2002, p. 395). Thus, giving gum to these Japanese children can also be translated as an imposition of custom because 1940s Japanese never actually had gum as part of their custom or even their commodity. Meanwhile, American food is also imposed by U.S. occupation authority. At Nishiki Minami Middle School, once a week, U.S. soldiers arrive to give American food to Japanese students (Kutsukake, 2016). This is part of the school lunch program initiated by U.S. government during the occupation, which provided the Japanese students with American food including bread, powdered milk, and a meat-based stew (Arugumam, 2012). In this case, although it may consider as humanitarian 
aid, providing American food for postwar Japanese students significantly changes diet and custom in Japanese culture. In fact, during the occupation, American-led government announced that "the era of flour has arrived" which subsequently replaces rice a staple food in Japanese culture (Dower, 2000). In postcolonial standpoint, this aid consists of American propaganda to directly influence postwar Japanese to consume American-taste products. It significantly affects Japanese diet custom since American food had become a high demanded commodity for postwar Japanese due to two factors: its "lavishness" caused by American propaganda and famine caused by the war.

The last is the imposition of American fashion, which involves the concept of popular physical appearance. It includes clothing, footwear, lifestyle, accessories, make-up, and hairstyle. Western clothing (yofuku) and other popular style clothing are imposed to postwar Japanese society through media and social obligation. In this story, Japanese newspaper passage, which was found by Fumi (Kutsukake, 2016), shows two important points: the successful U.S. occupation program (writing letter for General MacArthur) and the implicit introduction of American fashion in the form of American glasses wore by this war veteran. The Japanese media such as radio and newspaper are used not only to spread its democratization programs but also to spread American commodities including style of fashion. Meanwhile, like media depiction, the imposition of American fashion can also be seen in the social obligation. In this novel, Mr. Harada forces his women employees to dress in American-style fashion which is described as heavy makeup, skirt, high heels etc. (Hollywood-oriented) (Kutsukake, 2016). He forces these young women to change their fashion-style from wearing traditional monpe pantaloons to American fashion. It is a requirement that standardizes the appearance of women in postwar Japan. Despite opposing Japanese tradition, for these young Japanese women, wearing American-style or specifically Hollywoodstyle fashion is able to gain high-class status in the middle of postwar Japanese society. Therefore, the imposition of American fashion establishes a new social class, which defines Western clothing (yofuku), specifically American clothing in its highest position.

\section{Postwar Japanese adoption toward American cultural imposition in Lynne Kutsukake's The Translation of Love}

As a continuation of cultural imposition, this part attempts to discuss the cultural adoption by postwar Japanese as impacts of cultural imposition during U.S. occupation. The finding shows that postwar Japanese adoption toward American cultural imposition is divided into four forms of adoption: language, Western dating, custom and fashion.

English is adopted by postwar Japanese characters that came from various social backgrounds such as schoolchildren, professionals, and prostitutes. For instance, for Kondo, who works as a teacher at Minami Nishiki Middle School and as freelance translator at Love Letter Ally (Koibumi Yokocho), English brings social and economic benefits for him. When working as a freelance translator, he sells his service by praising the superiority of English as "the language of U.S. soldiers" (Kutsukake, 2016, p. 41). In this case, English strengthens his position as a schoolteacher who used to be condemned for his knowledge of the enemy's language (tekikokugo). Previously, 
Nugroho, B.S., \& Rokhman, M.A. (2020). Imposition, adoption, and resistance in Lynne Kutsukake's The Translation of Love: A postcolonial approach. EduLite: Journal of English Education, Literature, and Culture, 5 (2), 345-358. DOI: http://dx.doi.org/10.30659/e.5.2.345-358

during prewar and wartime period, English was rarely learned and spoken due to nationalist sentiments such as "education in Japan in Japanese" policy (Butler, 2007, p. 131) and anti-patriotic sentiments such as tekikokugo (enemy's language) policy (Johnston, 2015). Meanwhile, many Japanese children brokenly speak English to U.S. soldiers such as Matt and Eddie, who are always targeted for Japanese children to be asked for chocolate and gum (Kutsukake, 2016). At this point, English becomes a tool for these children to gain the occupiers' preferable goods such as sweets, chocolate, gum and even cigarette. Then, for postwar Japanese women who either work as panpan girls or seek romantic liaison with U.S. soldiers, English is one of the most important American aspects to be imitated. For instance, a bar girl or panpan girl in Ginza ("women of the night" or "streetwalkers" who could be easily identified with Hollywood-style fashion) began to address Matt and Eddie in basic and seductive English greeting "Come on, honey" (Kutsukake, 2016, p. 139). At this point, the interaction between U.S. soldiers and panpan girls creates a pidgin called "Panlish" which is a colloquial English spoken by panpan girls (Sakamoto, 2010). This Japanese pidgin, panlish is one of the results of this new transcultural forms which created by the negotiation between U.S. soldiers and postwar Japanese.

Mimicking the language of the colonizer is a fundamental transition for accepting the "foreignness" within a native's culture. Shakib explains that language functions as a gateway of cultural identity. When the colonizer's language is adopted, there will be the adoption of other colonizer's cultural values and products (2011). It strengthens the domination and superiority of the colonizer. There is degradation of Japanese pride dealing with their national purity which used to refuse to accept the claim of otherness by the West.

Another adoption is Western dating (abekku), which shows the fraternization or social engagement between U.S. soldiers and postwar Japanese women, especially bar girl, panpan girl and "only" (a panpan girl who was loyal to a single American patron). For instance, during his visit in Hibiya Park, Matt encounters many Japanese from various social backgrounds, who enjoy this large public space, including U.S. soldiers with their Japanese spouses and Japanese men with their Japanese women,

GIs [U.S. soldiers], many in uniform, were also out in large numbers, sauntering alone or in groups, cameras slung around their necks. And then there were the couples. The Japanese couples walked shyly side by side, never touching, but the GIs always held hands with their Japanese girlfriends. (Kutsukake, 2016, p. 52)

Postwar Japanese couples, as represented by those Japanese couples in Hibiya Park, start adopting "free relations between men and women" jiyu na danjo ko-sai) introduced by U.S. soldiers which manifested into abekku (means "Western-style" dating couple) (McLelland, 201). Thus, it is considered as a process of cultural adoption that shows the significant impacts of U.S. occupation in postwar Japan.

At this point, a male and female relationship (danjo ko-sai) tends to shift from Confucian-style into American-style, which emphasizes on personal 
freedom. American lifestyle becomes a correct model of the society, which should be followed by postwar Japanese in order to reform themselves as "recognizable Other". As a result, postwar Japanese began to free themselves from traditional norms and cultural value that exist as part of Japanese cultural characteristics. In a broader perspective, young adults are adaptive toward social changes since young adult is an age of identity construction, which is eager and willing to fuse their identity with others (Erikson, 1977). Therefore, the cultural adoption of Western dating (abekku) which mostly conducted by postwar Japanese young adults resembles the significance of American cultural imposition regarding dating and free relation between men women in postwar Japanese society.

The third adoption is American customs such as chewing gum and bread-based diet custom. For instance, many postwar Japanese children and panpan women do not feel remorse to follow and copy U.S. soldiers' behavior including chewing gum (Kutsukake, 2016). Gum, as an iconic and popular symbol of "American invention" in 1930s and 1940s, represents American industrial prosperity during and after World War II. Since during U.S. occupation American culture becomes "a correct model" of the society, postwar Japanese blindly adopt it. Meanwhile, the presence of U.S. soldiers during the occupation, changes postwar Japanese custom on a diet. As part of humanitarian aid, American food began to be imposed to postwar Japan, especially in Japanese schools, including Minami Nishiki Middle (Kutsukake, 2016). This policy unconsciously switches postwar Japanese diet rice-based custom from their traditional food to American food which mostly wheatbased. American food represents the process of Americanization of postwar Japan under the direction of American capitalist power. Dower says, the consumption of bread and other wheat-based food imposed by U.S. occupation authority is not only a matter of survival but it is "a small manifestation of the horizontal Westernization that reached into every corner of society" (Dower, 2000 , p. 170). This consumption of American diet custom eliminates the element of nativeness and simultaneously endorses the foreignness of the colonizer's culture.

The last adoption is American fashion which is adopted mostly by postwar Japanese women who work closely with U.S. soldiers such as bar girls and panpan girls. They undergo a major cultural transformation by adopting American fashion, which includes the use of Western clothing (yofuku), haircut and make-up. It further becomes an obsession that is part of a new cultural identity for postwar Japanese women. For instance, Hisayo, a teenager who works as a bar girl, explains and expresses her admiration toward American clothing (Kutsukake, 2016). She refers American nightgown as "what a real woman wears" which means that it shows her obsession and admiration as the colonized. She considers American woman as a "true woman" that should be followed since during the occupation U.S occupation authority sets up "a glamorous white American" as a role model and ideal beauty for postwar Japanese women and girls to emulate (McAndrew, 2011). In other words, Hisayo's admiration toward American coat represents the obsession of postwar Japanese women, specifically young panpan girls to be "a 
Nugroho, B.S., \& Rokhman, M.A. (2020). Imposition, adoption, and resistance in Lynne Kutsukake's The Translation of Love: A postcolonial approach. EduLite: Journal of English Education, Literature, and Culture, 5 (2), 345-358. DOI: http://dx.doi.org/10.30659/e.5.2.345-358

modern and stylish woman". Thus, there is a racial and cultural obsession of being "White" within postwar Japanese society.

Furthermore, for Sumiko, who works as a bar girl in Mr. Harada's dance club (which is specifically intended for American guests), dressing like American women gives a sense of power because it makes her feel powerful, wanted, and superior as a woman (Kutsukake, 2016. It further becomes the pride for bar girls and panpan girls to dress in Western or American clothing (yofuku) because American-style fashion later defines the status of these Japanese women during U.S. occupation. Despite receiving negative stigma and social criticism from elder generation, dressing as American woman becomes very common behavior for young Japanese women and becomes a utopian dream for many postwar Japanese women in which some of them cannot afford to buy it (Kutsukake, 2016). Adopting American fashion is the reflection of a new young Japanese society that does not want to be tied by traditional norms. In fact, for some young Japanese women, dressing as American women resembles a form of "American Dream" in which they want to be recognized by the new constructed Japanese society and hope to have a romantic liaison with U.S. soldiers.

On the other hand, these young Japanese women, including Sumiko, cannot fully adopt American fashion due to the elements of nativeness, which physically and culturally attached to them. In other words, while mimicking white American woman, who is regarded as a "true woman", they cannot erase a racial difference that physically differentiates between Caucasian women (American) and Mongoloid (Japanese). Therefore, the American or Hollywood ideal beauty, which is implicitly propagated and disseminated through Japanese media during the occupation, cannot be fully achieved by these young Japanese women due to these racial and cultural differences. This colonial adoption only results in a "blurred copy" of American women.

\section{Postwar Japanese symbolic resistance in Lynne Kutsukake's The Translation of Love}

The finding of this part shows that, beside imposition and adoption, there is also a resistance from postwar Japanese toward the domination of the United States. The massive "Americanization" cannot be entirely accepted by some elements within postwar Japanese society, especially for Japanese who adopt traditionalist and nationalist point of view such as Kondo and former Japanese soldiers. It results in the emergence of symbolic resistance throughout the story. This issue is divided in the form of symbolic resistance into two: covert and overt symbolic resistance.

Covert symbolic resistance appears due to Japanese media censorship and control by U.S. occupation authority. In this context, while teaching his students at Minami Nishiki Middle School, Kondo symbolically expresses his resistance toward the presence of U.S. soldiers in his country by saying "Go home' and "Go home, GI Joe" while notices a new repatriated student from Canada, Aya Shimamura who also speaks English like U.S. soldiers (Kutsukake, 2016). Although he does not mainly hate the presence of U.S. soldiers but he expresses his unwillingness to be controlled by U.S. soldiers for an extended period. The words "it seemed as if they had already been here 
long enough" emphasizes Kondo's reluctance to be authorized by U.S. soldiers. His statement is a covert-style of symbolic resistance, which implies his nationalist expression as a Japanese citizen. In political standpoint, nationalism is defined as a patriotic feeling, principle or effort that consists of self-determination to govern itself without a foreign interference (Finlayson, 2014). In other words, nationalism embodies a spirit of anti-colonialism (Kodsy, 2015). In this context, Kondo's simple expression emphasizes the small manifestation of nationalism in which Japanese citizens should be more involved in democratizing postwar Japan, instead of relying on the United States as the occupying power.

On the other hand, overt symbolic resistance publicly and openly consists of subversive gesture toward the United States as foreign occupying power. In this novel, Allied Translator and Interpreter Service (ATIS) that works to translate documents from Japanese civilian to General McArthur as Supreme Commander for the Allied Powers (SCAP), often find some letters that consist of subversive gesture toward U.S. occupation authority, "Get out, Americans. Some letters were written in blood" (Kutsukake, 2016, p. 27). The subversive words in these letters illustrate the reluctant of the Japanese to be authorized by a foreign power under the form of military occupation. In this context, even when U.S. occupation authority dictates the socio-cultural aspects of postwar Japanese society, there is a robust nationalist character of Japanese civilization that cannot be easily erased. Although, the imposition and adoption of American cultures switch the cultural orientation of postwar Japanese, the proud of Japanese civilization, which distinguishes them with the West, still fundamentally exists. However, the resistance, which can be seen in the novel, is not enough to stem the flow of "Americanization" brought by the United States as the foreign occupying power.

\section{CONCLUSION}

The analysis of Lynne Kutsukake's The Translation of Love shows that there are cultural issues of cultural imposition, adoption and symbolic resistance that emerge due to the presence of U.S. servicemen as the occupying power in postwar Japan. In cultural imposition, the United States manages to impose American ideology, language, lifestyle, customs and fashion through various ways such as media, social interaction, social obligation and school curriculum. Meanwhile, in cultural adoption, postwar Japanese adopt American cultures in which it asserts that there is a shift of postwar Japanese cultural orientation that tends to be "American-oriented". In other words, for some of postwar Japanese, this cultural adoption can be regarded as a "sign of liberation" from the exhaustion of the war and their own ultra-nationalist government. Then, in symbolic resistance, due to the strong censorship and control on Japanese media by U.S. occupation authority, which then combines with kyodatsu, postwar Japanese resistance toward the United States as the occupying power, is only manifested in subversive everyday gestures which include covert and overt form. The analysis shows the construction of new Japanese society, which is strongly built under American influence. Moreover, it further implies the devaluation of Japanese culture, the humiliation of 
Nugroho, B.S., \& Rokhman, M.A. (2020). Imposition, adoption, and resistance in Lynne Kutsukake's The Translation of Love: A postcolonial approach. EduLite: Journal of English Education, Literature, and Culture, 5 (2), 345-358. DOI: http://dx.doi.org/10.30659/e.5.2.345-358

postwar Japanese people, and the birth of Japanese cultural dependency toward American culture.

\section{REFERENCES}

Aizawa, Y., \& Whatley, M. (2006). Gender, Shyness, and IndividualismCollectivism: A Cross-Cultural Study. Race, Gender \& Class, 13 (1/2), 7 25

Arieli, Y. (1964). Individualism and Nationalism in American Ideology. Cambridge: Harvard University Press.

Arumugam, N. (2012). Waves of Grain: How did Japan Come to Prefer Wheat over Rice? Retrieved on December 15th 2019 from http://slate.com/human-interest/2012/04/wheat-in-japan-how-thenation-learned-to-love-the-american-grain-instead-of-rice.html

Ashcroft, B., Griffiths, G., \& Tiffin, H. (2007). Post-Colonial Studies: The Key Concepts. New York: Routledge.

Balkin, J. (2016). Cultural Democracy and the First Amendment. Faculty Scholarship Series, 116 (5), 1053-1096

Bhabha, H. (2004). The Location of Culture. London and New York: Routledge.

Borton, H. (1948). American Occupation Policies in Japan. Proceedings of the Academy of Political Science, 22 (4), 37-45

Butler, Y. (2007). Foreign Language Education at Elementary Schools in Japan: Searching For Solutions amidst Growing Diversification. AsiaPacific Education, Language Minorities and Migration (ELMM) Network Working Paper Series, 3, 129-147

Connolly, J. (2018). The Experience of Occupation in the Nord, 1914-18. London: Manchester University Press.

Creswell, J. (2007). Qualitative Inquiry and Research Design: Choosing among Five Approaches (2nd Ed.). Thousand Oaks: SAGE Publications, Inc.

Dower, J. (2000). Embracing Defeat: Japan in the Wake of World War II. New York: WW Norton \& Company.

Erikson, E. (1977). Childhood and Society. London: Paladin Grafton Books.

Finlayson, A. (2014). "Nationalism" in V. Geoghegan and R. Wilford (Eds.), Political Ideologies: An Introduction (pp. 100-102). New York: Routledge.

Fluck, W., Brandt, S., \& Thaler, I. (2007). Introduction: The Challenges of Transnational American Studies. REAL - Yearbook of Research in English and American Literature 23, 1-7

Fujimoto-Adamson, N. (2006). Globalization and History of English Education in Japan. Asian EFL Journal, 8 (3), 259-282

Geertz, C. (1973). The Interpretation of Cultures. New York: Basic Books.

Huddart, D. (2006). Homi K. Bhabha. New York: Routledge 
Johnston, E. (2015). Truth Hurts: Censorship in the Media. Retrieved on December $\quad 5^{\text {th }}$ 2019, from https://www.japantimes.co.jp/news/2015/08/08/national/history/trut h-hurts-censorship-media/\#.XeuLwRsxX6Q

Kodsy, Y. (2015). Anti-colonialism, grassroots nationalism and their impacts on international relations in Egypt. Retrieved on January 1 ${ }^{\text {st }}, 2020$, from https://www.opendemocracy.net/en/north-africa-west-asia/anticolonialism-grassroots-nationalism-their-impacts-on-international-/

Kortright, C. (2003). Colonization and Identity. Retrieved on October 25th, 2019, from http://theanarchistlibrary.org/library/chris-kortrightcolonization-and-identity

Kumano, R. (2007). The US Occupation and Japan's New Democracy. Educational Perspectives, 40 (1), 36-43

Kutsukake, L. (2016). The Translation of Love. New York: Penguin Random House.

Leedy, P. (1985). Practical Research. New York: Macmillan Publishing Company.

Loomba, A. (2005). Colonialism/Postcolonialism. New York: Taylor \& Francis Group.

Lukes, S. (1978). Individualism. New York: Harper \& Row.

Mahsun. M. (2005). Metode Penelitian Bahasa: Tahapan Strategi, Metode, dan Tekniknya. Jakarta: PT. Raja Grafindo Persada.

Makodamayanti, S., \& Wulandari, D. (2019). Diasporic experiences portrayed in Luling character as the first-generation in Amy Tan's The Bonesetter's Daughter. EduLite Journal of English Education, Literature, and Culture, 4 (2), 216-225, DOI: http://dx.doi.org/10.30659/e.4.2.216-225

Markus, H., \& Kitayama, S. (1991). Culture and the Self: Implications for Cognition, Emotion, and Motivation. Psychological Review, 98 (2), 224 253, DOI: 10.1037/0033-295X.98.2.224

McAndrew, M. (2014). Beauty, Soft Power, and the Politics of Womanhood During the U.S. Occupation of Japan, 1945-1952. Journal of Women's History, 26 (4), 83-107

McLelland, M. (2010). "'Kissing is A Symbol of Democracy!' Dating, Democracy, and Romance in Occupied Japan, 1945-1952". Journal of the History of Sexuality, 19 (3), 1-28

McLelland, M. (2012). Love, Sex, and Democracy in Japan during the American Occupation. New York: Palgrave Macmillan.

Redclift, M. (2002). Chewing Gum in the United States and Mexico: the Everyday and the Iconic. Sociologia Ruralis, 42 (4), 391-403, DOI: $10.1111 / 1467-9523.00223$ 
Nugroho, B.S., \& Rokhman, M.A. (2020). Imposition, adoption, and resistance in Lynne Kutsukake's The Translation of Love: A postcolonial approach. EduLite: Journal of English Education, Literature, and Culture, 5 (2), 345-358. DOI: http://dx.doi.org/10.30659/e.5.2.345-358

Roibu, I., \& Roibu, P. (1917). The Differences between Women Executives in Japan and Romania. Oradea Journal of Business and Economics, 2 (1), 81-90

Rowe, J. (2014). Featured Articles: Three Articles on Transnationalism and American Studies. American Studies Association. Retrieved on July 15th, 2014,

from http://www.theasa.net/project_eas_online/page/project_eas_online_eas_ featured_article/

Sakamoto, R. (2010). Pan-Pan Girls: Humiliating Liberation in Postwar Japanese Literature. PORTAL Journal of Multidisciplinary International Studies, 7 (2), 1-15

Scott, J. (1985). Weapons of the Weak: Everyday Forms of Peasant Resistance. New Haven: Yale University Press.

Shakib, M. (2011). The Position of Language in Development of Colonization. Journal of Languages and Culture, 2 (7), 117-123

Tocqueville, A. d. (1990). Democracy in America. Volume 2. Translated by H. Reeve. New York: Vintage.

Trilby, K. (2016). Review: Lynne Kutsukake's The Translation of Love Offers Rich Insights into an Underreported Period. Retrieved on October $18^{\text {th }}$, 2019, from https://www.theglobeandmail.com/arts/books-andmedia/book-reviews / review-lynne-kutsukakes-the-translation-of-loveoffers-rich-insights-into-an-underreported-period-inhistory/article29569056/

Watson, J.K. (2007). Imperial mimicry, modernisation theory and the contradictions of postcolonial South Korea, Postcolonial Studies, 10 (2), 171-190, DOI: 10.1080/13688790701348565

Young, R. (2016). Postcolonialism: An Historical Introduction. Oxford: John Wiley \& Sons, 1td. 